JRPB, Vol. 6, No. 2, September 2018, Hal. 172-180

DOI: https://doi.org/10.29303/jrpb.v6i2.79

ISSN 2301-8119, e-ISSN 2443-1354

Tersedia online di http://jrpb.unram.ac.id/

\title{
MEMPELAJARI KARAKTERISTIK PENGERINGAN KERUPUK SAYUR
}

\author{
Studying The Drying Characteristics of Vegetable Crackers
}

\author{
Annie Widya Subagya ${ }^{1, *}$, Tamrin $^{1}$, Cicih Sugianti ${ }^{1}$, Diding Suhandy ${ }^{1}$ \\ ${ }^{1}$ Jurusan Teknik Pertanian, Fakultas Pertanian, Universitas Lampung \\ Email*):subagyaannie@gmail.com
}

Diterima: Agustus 2018

Disetujui: September 2018

\begin{abstract}
Crackers is one of the popular food products among the people of Indonesia. The addition of cassava leaves into crackers take advantage of the availability of cassava leaves, especially during harvesting. The research aims to determine some parameters of drying characteristics of vegetable crackers. Drying crackers were conducted using sun drying and rack dryers with the temperature of $50{ }^{\circ} \mathrm{C}$ and crackers's thickness of $2 \mathrm{~mm}, 3 \mathrm{~mm}$, and $4 \mathrm{~mm}$. The results showed that drying using dryer with cracker's thickness of $2 \mathrm{~mm}$, $3 \mathrm{~mm}$, and $4 \mathrm{~mm}$ spent a drying time about 3.5-4.5 hours that was faster than sun drying around 4.5 - 5.5 hours. The decrease of moisture content in the dryer was quicker than sun drying. The final moisture content of cracker using dryer had average value of $8.28 \%$ which was lower than the sun drying of $12.95 \%$. The color changes that occured after the drying process using dryer and sun drying produced value $<0.5$ which had a meaningless or unchanged after the drying process. Depreciation of material diameter on dryers had a value of $11.92 \%$ which was greater than that of sun drying. The mean of moisture balance $(\mathrm{Me})$ in the dryer of $7.348 \%$ wb (equilibrium moisture content) was lower than using sun drying. Drying constant of crackers value using dryer had an average value of 1.196 /hours that was higher than using the sun drying of 0.84 /hour.
\end{abstract}

Keywords: vegetable crackers, sun drying, rack dryer, drying constants

\begin{abstract}
ABSTRAK
Kerupuk merupakan salah satu produk makanan kering yang populer dikalangan masyarakat Indonesia. Penambahan daun singkong kedalam adonan kerupuk untuk memanfaatkan ketersediaan daun singkong terutama saat panen. Penelitian ini bertujuan untuk mengetahui beberapa karakteristik pengeringan kerupuk sayur. Pengeringan kerupuk dilakukan dengan metode penjemuran konvensional di bawah sinar matahari dan alat pengering tipe rak dengan suhu pengering $50^{\circ} \mathrm{C}$ ketebalan $2 \mathrm{~mm}, 3 \mathrm{~mm}, 4 \mathrm{~mm}$. Hasil penelitian menunjukkan bahwa pengeringan menggunakan alat pengering dengan
\end{abstract}


ketebalan $2 \mathrm{~mm}, 3 \mathrm{~mm}$, dan $4 \mathrm{~mm}$ memiliki waktu pengeringan selama 3,5-4,5 jam yang lebih cepat dibandingkan dengan pengeringan sinar matahari dengan perlakuan yang sama membutuhkan waktu yaitu 4,5-5,5 jam. Penurunan kadar air pada alat pengering lebih cepat dibandingkan dengan pengeringan dengan sinar matahari. Kadar air akhir pada pengeringan menggunakan alat pengering tipe rak memiliki nilai rata-rata 8,28\% yang lebih rendah dibandingkan pengeringan sinar matahari yaitu $12,95 \%$. Perubahan warna yang terjadi setelah proses pengeringan menggunakan alat pengering dan sinar matahari menghasilkan nilai $<0,5$ yang memiliki arti kurang jelas atau tidak mengalami perubahan setelah dilakukan proses pengeringan. Penyusutan diameter bahan pada alat pengering memiliki nilai 11,92\% yang lebih besar dari pengeringan sinar matahari. Nilai rata-rata kadar air keseimbangan (Me) pada alat pengering yaitu 7,348 lebih rendah dibandingkan pada pengeringan sinar matahari. Nilai konstanta pengeringan pada alat pengering lebih memiliki nilai $12,05 \%$ lebih tinggi dibandingkan dengan pengeringan sinar matahari yaitu $8,28 \%$.

Kata kunci: kerupuk sayur, pengeringan sinar matahari, pengeringan alat tipe rak, konstanta pengeringan.

\section{PENDAHULUAN}

Kerupuk merupakan produk makanan kering yang telah lama dikenal masyarakat Indonesia. Konsumsi kerupuk biasanya bukan sebagai makanan utama melainkan sebagai makanan kecil, makanan ringan atau sebagai pelengkap hidangan yang umumnya dikonsumsi dalam jumlah kecil dan banyak penikmatnya. Jenis makanan ini hampir digemari oleh hampir semua lapisan masyarakat. Tidak heran sampai saat ini bisnis kerupuk masih banyak di produksi dan konsumennya juga semakin meningkat. Pada dasarnya bahan baku pembuatan kerupuk adalah tepung tapioka atau tepung singkong dimana tepung terigu merupakan produk impor dari luar Indonesia. Saat ini sudah banyak ditemui jenis kerupuk dengan berbagai variasi bahan tambahan seperti kerupuk dengan penambahan ikan, kerupuk bawang dengan penambahan bawang dan akhirakhir ini banyak kerupuk dengan penambahan berbagai jenis sayur seperti wortel, kentang dan lainnya (Wahyuningtyas, dkk., 2014). Kelompok Wanita Tani Mawar yang bertempat di Trimurjo Lampung Tengah membuat kerupuk sayur dengan tambahan daun singkong.

Pengeringan kerupuk sayur yang dilakukan masih secara alami atau menggunakan sinar matahari. Pengering alami dapat dilakukan dengan mudah pada daerah tropis, tetapi akan bermasalah saat musim hujan sebab bahan akan turun kualitasnya karena pengeringan terhambat. Untuk itu perlu dilakukan altenatif pengeringan kerupuk dengan menggunakan alat pengering tipe rak. Metode ini menggunakan udara panas yang dihembuskan ke bagian ruang pengering. Pengeringan mekanis bahan diletakkan pada rak pertama (Putro, 2016).

Tujuan penelitian ini yaitu membandingkan beberapa parameter karakteristik pengeringan kerupuk sayur dengan menggunakan sinar matahari dan menggunakan alat pengering tipe rak.

\section{METODE PENELITIAN}

\section{Waktu dan Tempat}

Penelitian dilaksanakan pada bulan September sampai Desember 2017 di Laboratorium Daya Alat dan Mesin Pertanian dan Laboratorium Bioproses 
Pasca Panen di Jurusan Teknik Pertanian Fakultas Pertanian Universitas Lampung.

\section{Alat dan Bahan}

Alat yang digunakan dalam penelitian ini meliputi para-para dan mesin pengeringan tipe rak 'tray drayer". Sedangkan bahan penelitian yang digunakan pada penelitian ini yaitu komposisi adonan yang dibuat sesuai petunjuk yang didapat dari Kelompok Wanita Tani Mawar.

\section{Metode Penelitian}

Penelitian ini menggunakan 2 perlakuan pengeringan, yaitu penjemuran konvensional di bawah sinar matahari dengan suhu rata-rata $36{ }^{\circ} \mathrm{C}$ dan menggunakan alat pengering tipe rak dengan suhu $50^{\circ} \mathrm{C}$ ) dan tingkat ketebalan irisan bahan kerupuk ( $2 \mathrm{~mm}, 3 \mathrm{~mm}$ dan 4 $\mathrm{mm}$ ). Irisan kerupuk ini disusun diatas rak pada alat pengering dengan tebal satu lapis. Sampel dari kerupuk sayur ditimbang setiap setengah jam, kemudian sampel dimasukkan lagi ke dalam ruang pengering. Pengamatan yang dilakukan adalah mengukur penurunan bobot, kadar air bahan, perubahan diameter kerupuk, dan perubahan warna, kadar air keseimbangan dan konstanta pengeringan.
Nilai konstanta pengeringan dengan cara simulasi dengan menggunakan persamaan 1 , dengan menggunakan metode kuadrat terkecil dengan sumbu y adalah $\ln (\mathrm{m}-$ $\mathrm{me}) /($ mo-me) dan waktu (t) sebagai sumbu $\mathrm{x}$.

$$
\frac{M-M e}{M 0-M e}=e^{(-k t)}
$$

Dimana:

$\mathrm{k} \quad$ : konstanta pengeringan (1/jam)

Mo : kadar air awal (\%)

Me : kadar air keseimbangan (\%)

M : kadar air pada waktu ke- $(\%)$

$\mathrm{t} \quad$ : waktu pengeringan (jam)

Warna kerupuk sayur diidentifikasi dengan menggunakan alat color meter tipe TES 135A. Color meter ini akan menghasilkan total perbedaan warna $\Delta$ $\mathrm{E}^{*}{ }_{\mathrm{ab}}$ juga dapat diistilahkan dengan TDC (total difference color) dan didefinisikan dengan persamaan berikut :

$$
\mathrm{TDC}=\sqrt{ }(\Delta \mathrm{L} *)^{2}+\left(\Delta \mathrm{a}^{*}\right)^{2}+\left(\Delta \mathrm{b}^{*}\right)^{2}
$$

Setelah menghasilkan nilai TDC kemudian gunakan tabel di bawah ini untuk menunjukkan besar kecilnya perbedaan nilai warna (TDC) sampel yang telah diberikan perlakuan.

Tabel 1. Pengukuran perubahan nilai warna pada uji $\mathrm{L}^{*} \mathrm{a}^{*} \mathrm{~b}^{*}$

\begin{tabular}{cc} 
Nilai TDC $($ TDC value $)$ & Perbedaan (Difference) \\
\hline$<0,5$ & Kurang jelas (trace) \\
$0,5-1,5$ & Sedikit/tipis (Slight) \\
$1,5-3,0$ & Agak terlihat (Noticeable) \\
$3,0-6,0$ & Terlihat (Appreciable) \\
$6,0-12$ & Banyak (Much) \\
$>12$ & Sangat banyak (Very much) \\
\hline
\end{tabular}

Sumber: Asgar, dkk., 2013. 


\section{HASIL DAN PEMBAHASAN}

\section{Penurunan Bobot Bahan}

Salah satu parameter untuk mengetahui tingkat keberhasilan selama proses pengeringan adalah berkurangnya bobot kerupuk setelah dilakukan pengeringan.

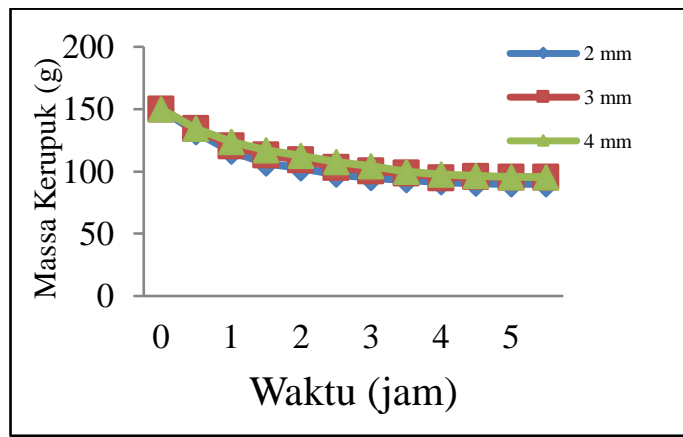

Gambar 1. Grafik penurunan bobot kerupuk selama proses penjemuran konvensional.

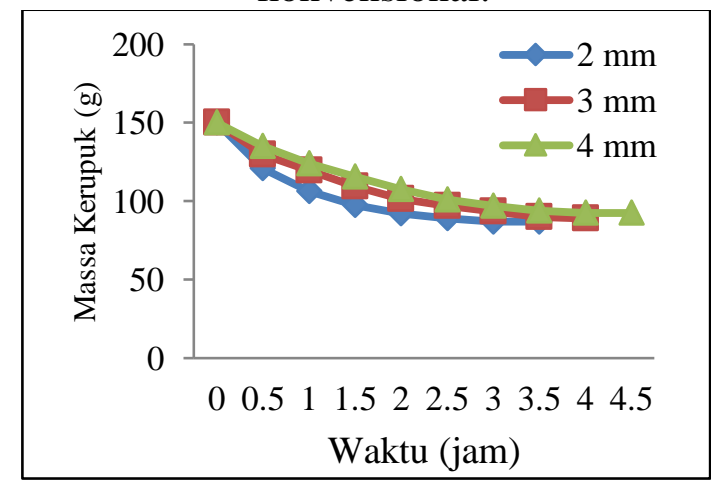

Gambar 2. Grafik penurunan bobot kerupuk selama proses pengeringan menggunakan alat pengering.

Penurunan bobot kerupuk terjadi secara eksponensial pada pengeringan dengan cara penjemuran dan alat pengering tipe rak, pada awal pengeringan penurunan bobot kerupuk terjadi secara cepat dan mendekati laju pengeringan konstan penurunan bobot bahan menjadi lambat. Hal ini dikarenakan pada awal pengeringan kandungan air yang terkandung didalam kerupuk masih banyak, sehingga penurunan terjadi secara cepat dan akan lambat pada saat kadar air yang terkandung didalam kerupuk tinggal sedikit. Pada pengeringan menggunakan alat pengering bobot kerupuk konstan dicapai lebih cepat dibandingkan dengan pengeringan menggunakan sinar matahari, karena suhu yang digunakan pada alat pengering lebih tinggi dibandingkan suhu yang didapat pada pengeringan dengan sinar matahari. Hal ini sesuai dengan pernyataan (Rachmawan, 2001) makin tinggi suhu dan kecepatan aliran udara pengering makin cepat pula laju pengeringan. Makin tinggi suhu udara pengering, makin besar energi panas yang dibawa udara sehingga makin banyak jumlah massa air yang diuapkan dari permukaan bahan yang dikeringkan.

Pengeringan sinar matahari, bahan dengan ketebalan $2 \mathrm{~mm} 3 \mathrm{~mm}$ dan $4 \mathrm{~mm}$ konstan pada waktu relatif bersamaan. Pengeringan menggunakan alat pengering dengan ketebalan $2 \mathrm{~mm}, 3 \mathrm{~mm}$ dan $4 \mathrm{~mm}$ memiliki kecenderungan perbedaan, dimana bahan dengan ketebalan $2 \mathrm{~mm}$ lebih cepat mencapai. Hal ini dapat dilihat pada Gambar 1 dan 2. Pada pengeringan matahari berat konstan didapat secara relatif bersamaan, hal ini diduga karena pengeringan dilakukan pada suhu rendah. Namun pada pengeringan menggunakan alat pengering bahan dengan ketebalan 2 $\mathrm{mm}$ lebih cepat mendapati berat konstan. Hal ini sesuai pendapat Muljoharo (1987) dalam Dwi (2008) yang menyatakan bahwa semakin tebal suatu bahan yang dikeringkan, maka semakin lama waktu pengeringannya. Karena, jarak yang ditempuh oleh panas untuk masuk ke bagian dalam bahan sekaligus menguapkannya menuju ke permukaan bahan jadi menurun.

\section{Penurunan Kadar Air}

Kadar air mengalami penurunan lebih cepat dengan semakin tingginya suhu pengeringan. Hal ini disebabkan semakin tinggi suhu pengeringan maka semakin cepat pindah panas dan penguapan air dari bahan pangan. 
Menurut Estiasih (2009) semakin besar perbedaan suhu antara medium pemanas dengan bahan pangan semakin cepat pindah panas ke bahan pangan dan semakin cepat pula penguapan dari bahan pangan.

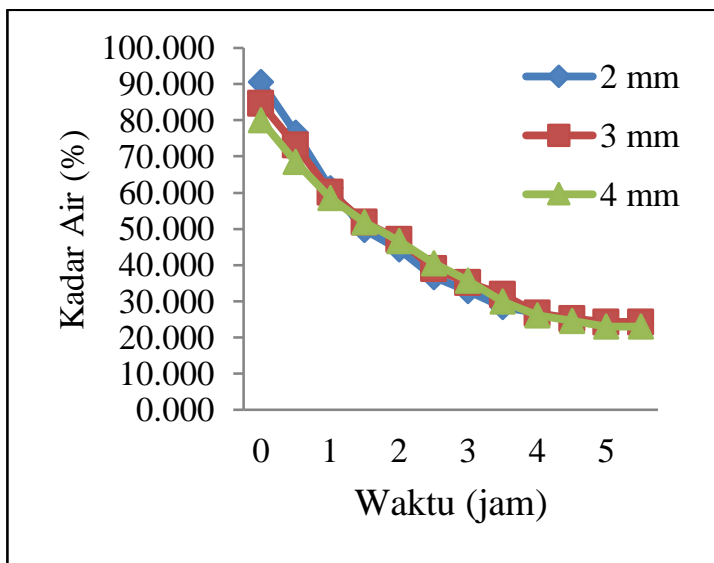

Gambar 3. Grafik penurunan kadar air kerupuk dengan waktu pada suhu ratarata $36^{\circ} \mathrm{C}$.

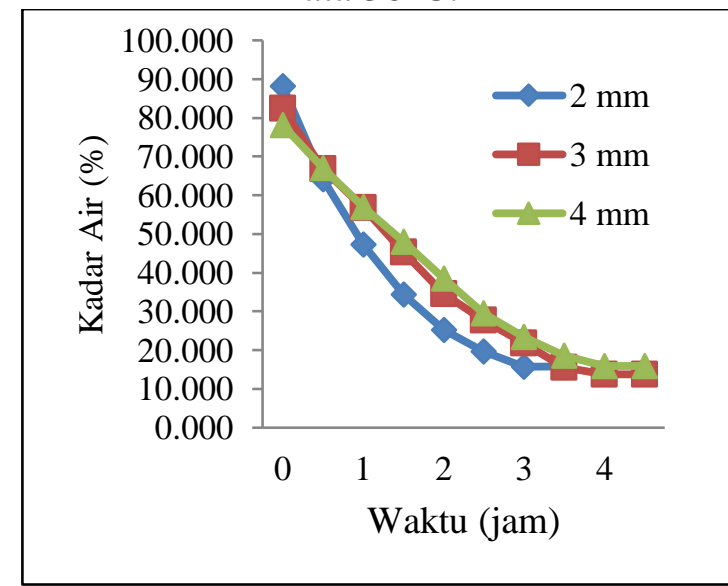

Gambar 4. Grafik penurunan kadar air kerupuk dengan waktu pada suhu ratarata $50^{\circ} \mathrm{C}$

Semakin berkurangnya bobot pada bahan menunjukkan bahwa kadar air yang tersisa semakin sedikit. Pada waktu yang sama, kadar air akhir terendah didapat pada pengeringan dengan menggunakan alat pengering tipe rak dibandingkan dengan pengeringan dengan sinar matahari. Hal ini disebabkan pengeringan menggunakan alat pengering tipe rak menggunakan suhu yang lebih tinggi yaitu $50^{\circ} \mathrm{C}$ dibandingkan dengan sinar matahari yaitu $36^{\circ} \mathrm{C}$. Nurcahyono, dkk. (2015) menyatakan bahwa kadar air mengalami penurunan dengan semakin tingginya suhu pengeringan. Hal ini disebabkan semakin tinggi suhu pengeringan maka semakin cepat pindah panas dan penguapan air dari bahan pangan.

Semakin tipis bahan semakin cepat penurunan kadar airnya hal ini dikarenakan air yang terkandung didalam bahan mudah teruapkan dari dalam bahan. Dilihat dari Gambar 2 kerupuk dengan ketebalan $2 \mathrm{~mm}$ memiliki grafik lebih landai dibandingkan dengan Gambar 3 dan Gambar 4.

\section{Perubahan Warna}

Warna merupakan salah satu parameter yang sangat penting sebagai indeks kualitas yang dapat diterima pada produk pangan. Karakteristik warna kerupuk sayur dilihat dari hasil pengukuran nilai $\mathrm{L}^{*}, \mathrm{a}^{*}$, dan $\mathrm{b}^{*}$ dalam bentuk sebelum dan sesudah dikeringkan.

Tabel 2. Nilai TDC pada Uji L* a* $b^{*}$ Kerupuk Setelah Pengeringan Dengan Sinar Matahari dan Alat Tipe Rak

\begin{tabular}{ccc}
\hline \multirow{2}{*}{$\begin{array}{c}\text { Ketebalan } \\
(\mathrm{mm})\end{array}$} & \multicolumn{2}{c}{ Nilai TDC } \\
\cline { 2 - 3 } & Sinar Matahari & Alat Tipe Rak \\
\hline 2 & 0,0520 & 0,0316 \\
3 & 0,0187 & 0,0214 \\
4 & 0,0252 & 0,0266 \\
\hline
\end{tabular}

Nilai TDC pada Tabel 2 yang didapat setelah proses pengeringan kemudian diterjemahkan pada Tabel 1 yang menunjukkan tingkat perubahan warna yang terjadi setelah proses pengeringan dilakukan. Kerupuk yang telah dikeringkan dengan sinar matahari dan alat tipe rak nilai TDC yang dihasilkan yaitu $<0,5$ yang artinya kurang jelas (trace) atau tidak mengalami perubahan yang berarti pada nilai $L^{*} a^{*} b^{*}$. 


\section{Perubahan Diameter Bahan}

Penyusutan biasanya merupakan karakteristik yang dapat diketahui dengan menentukan perubahan yang terjadi pada volume dan/atau dimensi bahan Wang, et al., (2002). Untuk mengetahui pengerutan yang terjadi perlu dilakukan perbandingan diameter awal bahan dan sesudah dikeringkan.

Tabel 3. Perubahan Fisik pada Pengeringan Kerupuk dikeringkan dengan Sinar Matahari

\begin{tabular}{cccc}
\hline $\begin{array}{c}\text { Ketebalan } \\
(\mathrm{mm})\end{array}$ & $\begin{array}{c}\mathrm{d} 1 \\
(\mathrm{~cm})\end{array}$ & $\begin{array}{c}\mathrm{d} 2 \\
(\mathrm{~cm})\end{array}$ & $\Delta \mathrm{d}(\%)$ \\
\hline 2 & 2,59 & 2,29 & 11,58 \\
3 & 2,57 & 2,35 & 8,56 \\
4 & 2,58 & 2,39 & 7,36 \\
\hline
\end{tabular}

Tabel 4. Perubahan Fisik pada Pengeringan Kerupuk Sebelum dan Sesudah dikeringkan dengan Tipe Rak

\begin{tabular}{cccc}
\hline $\begin{array}{c}\text { Ketebalan } \\
(\mathrm{mm})\end{array}$ & $\begin{array}{c}\mathrm{d} 1 \\
(\mathrm{~cm})\end{array}$ & $\begin{array}{c}\mathrm{d} 2 \\
(\mathrm{~cm})\end{array}$ & $\Delta \mathrm{d}(\%)$ \\
\hline 2 & 2,60 & 2,29 & 11,92 \\
3 & 2,57 & 2,35 & 8,56 \\
4 & 2,58 & 2,38 & 8,10 \\
\hline
\end{tabular}

Perubahan diameter yang terjadi dikarenakan kadar air yang terkandung didalam bahan hilang dan menyebabkan pengerutan pada bahan setelah dilakukan proses pengeringan. Tulliza, dkk. (2010) menyatakan penyusutan pada temu putih selama pengeringan terjadi karena menguapannya air selama proses pengeringan. Difusivitas bahan akan berkurang dengan berkurangnya kadar air. Tabel 3 dan 4 menunjukkan perubahan diameter pada bahan yang terjadi setelah proses pengeringan kerupuk sayur. Bahan dengan ketebalan $2 \mathrm{~mm}$ pada pengeringan dengan sinar matahari dan menggunakan alat tipe rak memiliki kecenderungan penyusutan lebih tinggi yaitu 11,58 $11,92 \%$, dibandingkan ketebalan $3 \mathrm{~mm}$ pada pengeringan sinar matahari dan rak yaitu $8,56 \%$ dan $4 \mathrm{~mm}$ pada pengeringan matahari $7,36 \%$ pada pengeringan tipe rak $8,10 \%$. Hal ini air lebih banyak keluar pada kerupuk yang dikeringkan dengan alat tipe rak dibandingkan dengan dijemur dibawah sinar matahari.

\section{Kadar Air Bahan}

Pada saat proses pengeringan, tekanan uap air didalam bahan lebih besar dibandingkan dengan tekanan uap air di dalam bahan. Hal ini menyebabkan air yang ada dalam bahan menguap, sehingga terjadi perpindahan massa uap air dari bahan ke udara. Pada tahap berikutnya, terjadi perpindahan air dari dalam bahan ke permukaan secara difusi sehingga penurunan kadar air bahan berlangsung lambat. Proses ini berlangsung sampai massa bahan konstan sehingga diperoleh kadar air keseimbangan.

Tabel 5. Data kadar air akhir kerupuk selama pengeringan

\begin{tabular}{ccccccc}
\hline \multirow{2}{*}{$\begin{array}{c}\text { Metode } \\
\text { Pengeringan }\end{array}$} & $\begin{array}{c}\text { Ketebalan } \\
(\mathrm{mm})\end{array}$ & \multicolumn{2}{c}{ Kadar air $(\% \mathrm{bb})$} & \multicolumn{2}{c}{ Kadar air (\%bk) } & \multirow{2}{*}{ Waktu (jam) } \\
\cline { 3 - 6 } Sinar matahari & 2 & 47,55 & 12,6 & 90,72 & 24,07 & $4,5-5,5$ \\
& 3 & 45,85 & 13,5 & 84,72 & 24,28 & $4,5-5,5$ \\
& 4 & 44,4 & 12,75 & 80,05 & 23,00 & $4,5-5,5$ \\
Alat pengering & 2 & 46,85 & 8,4 & 88,22 & 15,81 & 3,5 \\
& 3 & 45,15 & 7,5 & 82,38 & 13,77 & $4-4,5$ \\
& 4 & 43,8 & 8,95 & 78,07 & 15,98 & $4-4,5$ \\
\hline
\end{tabular}

Pengeringan dengan suhu semakin tinggi maka waktu yang diperlukan untuk proses pengeringan semakin cepat dan kadar air akhir bahan semakin rendah, 
sebaliknya semakin tebal pengirisan bahan maka waktu yang diperlukan untuk pengeringan semakin lama dan kadar air yang dihasilkan semakin tinggi. Pada pengeringan dengan menggunakan alat pengeringan didapat kadar air akhir 13,7 $15,81 \%$, sedangkan pengeringan cara penjemuran menghasilkan kadar air akhir $23,0-24,3 \%$.

Perlakuan pengeringan dan ketebalan dalam penelitian ini tidak memberikan pengaruh yang konsisten terhadap penurunan/peningkatan kadar air akhir yang dihasilkan. Pada pengeringan matahari hal ini disebabkan suhu matahari yang tidak stabil dan waktu pengeringan yang dibutuhkan tidak sama. Menurut Sagita (2013) pada pengeringan dengan menggunakan alat pengeringan, adanya kondisi ketidak stabilan kontrol suhu alat pengering pada saat pengeringan. Selain itu waktu pengeringan yang berbeda pada saat pengeringan dengan alat pengering mempengaruhi ketidak konsistenan hal tersebut.

Kadar Air Keseimbangan

Tabel 6. Nilai Me (Kadar air keseimbangan)

\begin{tabular}{ccc}
\hline \multirow{2}{*}{$\begin{array}{c}\text { Ketebalan } \\
(\mathrm{mm})\end{array}$} & \multicolumn{2}{c}{ Me (\%bb) } \\
\cline { 2 - 3 } & $\begin{array}{c}\text { Sinar } \\
\text { Matahari }\end{array}$ & Alat rak \\
\hline 2 & 12,25 & 7,485 \\
3 & 12,00 & 7,300 \\
4 & 11,90 & 7,260 \\
\hline Rata-rata & 12,05 & 7,348 \\
\hline
\end{tabular}

Kadar air keseimbangan (Me) diperlukan diketahui pada saat pengeringan suatu produk pertanian. Me berguna untuk menentukan bertambah atau berkurangnya kadar air bahan pada kondisi suhu dan RH udara tertentu (Brooker, dkk., 1974). Tabel 6 menunjukkan nilai rata-rata nilai Me yang diperoleh selama proses pengeringan dengan sinar matahari dengan ketebalan 2 $\mathrm{mm}, 3 \mathrm{~mm}, 4 \mathrm{~mm}$ yaitu 12,05\% bb, pada pengeringan menggunakan alat pengering dengan ketebalan $2 \mathrm{~mm}, 3 \mathrm{~mm}, 4 \mathrm{~mm}$ nilai Me yang diperoleh yaitu 7,348\% bb.

Semakin tinggi suhu yang digunakan pada saat proses pengeringan semakin kecil nilai Me yang dihasilkan. Hal ini sesuai menurut Brooker, dkk., (1981) kadar air keseimbangan akan semakin menurun apabila suhu ruang pengering semakin meningkat. Hal ini disebabkan karena pada ruang pengering dengan kondisi suhu yang tinggi akan memiliki kelembaban relatif yang rendah sehingga laju penguapan akan semakin banyak dan lebih besar. Bahan dengan ketebalan $2 \mathrm{~mm}$ pada pengeringan sinar matahari dan pengering mekanis memiliki nilai kadar air keseimbangan yang lebih besar, dibandingkan dengan ketebalan 3 $\mathrm{mm}$ dan $4 \mathrm{~mm}$, hal ini menunjukkan bahwa semakin tipis bahan yang dikeringkan semakin banyak air pada bahan yang teruapkan.

\section{Konstanta Pengeringan}

Tabel 7. Konstantan Pengeringan (k) pengeringan sinar matahari dan Alat Tipe Rak

\begin{tabular}{ccc}
\hline \multirow{2}{*}{$\begin{array}{l}\text { Ketebalan } \\
(\mathrm{mm})\end{array}$} & $\begin{array}{c}\text { Sinar } \\
\text { Matahari }\end{array}$ & Alat Rak \\
\cline { 2 - 3 } & $\mathrm{k}\left(\mathrm{jam}^{-1}\right)$ & $\mathrm{k}\left(\mathrm{jam}^{-1}\right)$ \\
\hline 2 & 1,051 & 1,340 \\
3 & 0,800 & 1,069 \\
4 & 0,669 & 1,179 \\
\hline Rata-rata & 0,840 & 1,196 \\
\hline
\end{tabular}

Dari Tabel 7 diketahui nilai koefesien tertinggi yaitu pada alat pengering dengan suhu pengeringan $50^{\circ} \mathrm{C}$. Rahayoe, dkk. (2008) menyatakan konstanta pengeringan meningkat dengan semakin meningkatnnya suhu pengeringan. Semakin tinggi suhu udara pengering maka nilai $\mathrm{k}$ semakin besar karena panas yang diberikan semakin 
tinggi dan penguapan air juga semakin cepat.

Bahan dengan ketebalan yang lebih tipis menghasilkan nilai $\mathrm{k}$ yang lebih tinggi, dapat dilihat pada Tabel 7 perlakuan bahan dengan ketebalan pengirisan $2 \mathrm{~mm}$ pada pengeringan dengan sinar matahari dan alat pengering memiliki nilai konstanta pengeringan lebih besar, hal ini dikarenakan air yang terkandung didalam bahan mudah teruapkan. Namun terdapat fenomena lain yaitu nilai konstanta pada ketebalan 3 lebih rendah dibandingkan dengan bahan ketebalan 4 $\mathrm{mm}$. Menurut Sagita (2013) besarnya nilai konstanta pengeringan dipengaruhi oleh kadar air awal bahan, kadar air selama pengeringan, waktu pengeringan, suhu, RH, dan kecepatan udara pengering. Semakin tinggi nilai konstanta pengeringan menunjukkan semakin cepat suatu bahan membebaskan kandungan air.

\section{KESIMPULAN}

Laju pengeringan bahan dengan menggunakan alat pengering tipe rak lebih cepat mendapati bobot konstan dibandingkan laju pengeringan bahan dengan sinar matahari. Kadar air pada pengeringan menggunakan alat pengering tipe rak lebih rendah dibandingkan dengan sinar matahari. Nilai Me pada alat pengering tipe rak lebih rendah daripada pengeringan dengan sinar matahari. Nilai $\mathrm{k}$ pada pengeringan menggunakan alat tipe rak lebih tinggi pada pengeringan menggunakan sinar matahari.

Selain itu, persentase perubahan fisik dalam bentuk pengerutan pada pengeringan menggunakan pengering tipe rak lebih besar dibandingkan pengeringan dengan sinar matahari. Perubahan warna yang terjadi setelah pengeringan dengan alat pengering tipe rak dan dengan sinar matahari menghasilkan rata-rata nilai TDC $<0,5$ yang artinya kurang jelas (trace) atau tidak mengalami perubahan yang berbeda dari warna awal sebelum pengeringan.

\section{DAFTAR REFERENSI}

Asgar, A., Zain, S., Widyasanti, A. dan Wulan, A. 2013. Kajian karakteristik proses pengeringan jamur tiram (Pleurotus sp.) menggunakan mesin pengering vakum. Jurnal hort. Vol. 4 (No. 23): Halaman 379-389

Brooker, D. B., Bakker-Arkena, F. W. and Hall, C. W. 1974. Drying Cereal Grains. Westport, Connecticut: The AVI Publishing Co., Inc.

Brooker, D. B., Barker-Arkema F. W., and Hall C W. 1981. Drying and Storage of Grain and Oilseeds. New York: Van Nostrand Reinhold

Dwi, M. 2008. Mempelajari karakteristik Pengeringan Chip Berbahan Campuran Ubi Kayu dan Ubi Jalar dengan Ketebalan yang Berbeda. Skripsi. Universitas Lampung. Lampung

Putro, M. R. 2016. Uji Kinerja Alat Pengering Mekanis Tipe Rak Untuk Mengeringkan Stick Singkong. Skripsi. Universitas Lampung. Lampung

Rachmawan, O. 2001. Pengeringan, Pendinginan, dan Pengemasan Komoditas Pertanian. Direktorat Pendidikan Menengah Kejuruan, Departemen Pendidikan Nasional. Jakarta.

Rahayoe, S., Budi, R. dan Rr., S. K. 2008. Konstanta laju pengeringan daun sambiloto menggunakan pengering tipe tekanan rendah. Jurnal rekayasa 
proses. Vol. 2 (No. 1). Halaman: 1723

Sagita, A. 2013. Hubungan Penyusutan dengan Karakteristik Pengeringan Lapisan Tipis Simpilisia Temulawak (Curcuma Xanthorrhiza Roxb.). Skripsi. Institut Pertanian Bogor. Jawab Barat

Tulliza, I. S., Armansyah, H. T., dan Usman, A. 2010. Pengaruh Penyusutan Temu Putih (Curcuma Zedoaria (Berg) Roscoe) Terhadap Karakteristik Pengeringan Lapisan Tipis. Jurnal Keteknikan Pertanian. Vol. 24 (No. 2). Halaman: 107-114
Wahyuningtyas, N., Basito. dan Windi, A. 2014. Kajian Karakteristik Fisikokimia dan Sensoris Kerupuk Berbahan Baku Tepung Terigu, Tepung Tapioka dan Tepung Pisang Kerupuk Kuning. Jurnal Teknosains Pangan. Vol. 3 (No. 2). Halaman 7685

Nurcahyono, I. D., dan Elok, Z. 2015. Pengaruh Konsentrasi Carboxymethyl Cellulose Sebagai Edible Coating dan Suhu Pengeringan Terhadap Sifak Fisik dan Kimia Wortel Kering Instan. Jurnal Pangan dan Agroindustri. Vol. 3 (No. 3) Halaman : 1192-1202 